\title{
TERRITORIAL FRAMEWORK OF LOCAL SELF-GOVERNMENT: BASIS OF LEGISLATIVE REGULATION
}

\author{
ZINOVIY SIRYK, ROSTYSLAV BILYK, OLENA PANUKHNYK
}

\begin{abstract}
Ukraine is increasingly trying to integrate into European structures. The civilizational, geopolitical and geo-economic choice for our country is obvious, therefore, difficult, consistent and sometimes unconventional and unpopular political decisions are required to implement it. The real implementation of the deconcentration, decentralization and subsidiarity principles in the practice of public administration is necessary, in particular, due to the introduction of new models of relations between the political center and the regions. Regional disproportions in the territory development of Ukraine, the failure to implement the reform on the ground in specific administrative and territorial units, the spread of corruption schemes - all these are the consequences of an ineffective model of local self-government and state management of regional development, that became the beginning of the administrative and territorial reform in the state. And in order to ensure a high-quality process of administrative and territorial reform, it is important, and to some extent and the most basic, is the process of adopting high-quality regulatory base for legislation. The article identifies the main directions for the formation of an effective management system at all levels, including: the formation of an optimal territorial basis, the provision of appropriate material, administrative, organizational and financial conditions for the implementation of the powers granted to them by local governments, a clear delineation of powers between management bodies of different levels based on decentralization, mechanism development of the state control and population involvement in the community development. The legislative base, which was adopted in the context of supporting the reform of local selfgovernment in Ukraine, has been analyzed. The legislative guidelines for the decentralization reform and regional policy in Ukraine have been determined and substantiated. Deficiencies and shortcomings of the normative-legal and institutional support system of the local self-government reform have been identified and ways of their elimination have been proposed.
\end{abstract}

Keywords: administrative and territorial reform, decentralization, self-government bodies, legal framework, territorial communities.

JEL Classification: O18, R11, R51.

\section{INTRODUCTION}

The current state of the state-building processes organization in Ukraine is characterized by the presence of a large number of problems, the main of which is the inconsistency of the organizational, functional, legal and socio-economic components with the conditions that are relevant for our state today. Speaking about the state of reforming the public administration sector, it can most often be 
described as unsatisfactory. When setting priorities, the central government proceeds from the needs of the state, but has poor understanding of the development needs of community and territories at the local level. Programs to stimulate the development of individual regions, the use of the cross-border cooperation practice, the introduction of the new organizing models in public-political processes. And one of the main reasons for this is the imperfect administrative and territorial structure of the state. It is not talking about the inefficiency or erroneousness of the unitarity and equality path of the regions chosen by Ukraine. But it should be understood that the uneven development of the regions, a large disproportion in the distribution of productive forces, the specificity of cultural and mental characteristics of various territorial communities puts Ukraine in front of the need to search for a new model of relations between the central and regional authorities, as well as regions among themselves, the implementation of the new regional cooperation forms on the subsidiarity and solidarity principles.

\section{Literature RevieW, Generalization of MAin Statements}

In the modern conditions in our country, the ideas of the territorial and administrative structure are especially relevant for the research and adaptation to the domestic financial, economic and management systems. Many scientists are engaged it in their research and analysis, in particular, M. Baimuratov, O. Batanov, V. Beschastnyi, V. Borschevskyi, P. Zhuk, O.V. Kampo, O. Kyrylenko, M. Kozoriz, V. Kravtsiv, V. Kravchenko, I. Lunina, M. Melnyk, H. Oleksiuk, Kh. Patytska, V. Pysmennyi, Yu. Rohozian, I. Storonianska, V. Fedosov, S. Shults and others.

Along with this, in the conditions of the reform stages passage, questions arise, the formation of a legislative base, which is the basis of all processes on formation and development of territorial communities, as well as the legality of their activities.

The purpose of the article is to analyze the legal framework for regulating the formation of territorial communities.

\section{Discussion}

In essence, investments in human capital are investments in intangible assets that accumulate and develop intangible resources for the productive activity of people, namely: knowledge, competencies, experience, health, social skills, intellectual and entrepreneurial abilities. Accordingly, depending on the investment purpose, the following components of human capital distinguish:

Local self-government is one of the most effective tools for local governance and territorial development. Where it really works, where the local population has a real right and opportunity to independently resolve issues of local importance, there is an increase in revenues of local budgets and socio-economic development in general.

In each state, depending on the characteristics of its political and territorial as well as administrative and territorial structure, the form of government and political regime, historical, national, geographical and other features, local self-government has a specific form and name.

The legitimacy of local self-government in Ukraine is confirmed by the Constitution and the Law of Ukraine "On Local Self-Government in Ukraine", that determine the system and guarantees of local self-government, the foundations of organization and activity, the legal status and responsibility of bodies and officials of local self-government.

Among all principles of the local self-government functioning determined by this law, the principle of legal, organizational and material and financial independence of local self-government, which it is endowed with within the powers determined by legislation, acquires special significance. Legal and organizational independence is expressed in the granting of certain powers to local governments, within which they act independently, make appropriate legal decisions, and are also responsible for the implementation of these powers. In addition, local self-government bodies may be granted separate powers of executive bodies, in the exercise of which they are subject to the control of the relevant executive bodies. 
The foundations of local self-government are economic, social, financial, legal and other opportunities and conditions that have objectively developed in society, the totality of which forms the basis on which the system of local self-government is built. These are the objects of reality on which the authority's activities are based, the resources they have. They are diverse in nature and in their object composition, which allows them to be classified.

One of these foundations of local self-government is the territorial basis, the consolidation of which is important, since local self-government is characterized primarily by certain spatial and graphic factors and can be carried out by a territorial community within the administrative boundaries of settlements [1, p. 86].

In addition to the Law of Ukraine "On Local Self-Government in Ukraine," an important document to substantiate the reform purpose is the Concept of local self-governance and territorial power reforming [2]. The problems identified for overcoming at the state level include:

- low level of quality and accessibility of social services as a result of resource insolvency by local authorities to ensure the implementation of their own and delegated powers;

- deterioration of water, sewer and heating networks, as well as the unsatisfactory state of the housing stock in the conditions of financial insolvency of the self-government bodies, to ensure their repair and return to normal condition, accompanied by an increase in accident rate and an increased risk of technological shocks;

- difficult demographic situation, which is manifested in an aging population, depopulation of rural areas and most monofunctional cities;

- inconsistency of local policies on the socio-economic development of the territory with the interests of communities in today's conditions;

- population lack in ensuring the development of community and solving issues of local importance, the absence of direct democracy institutions and cooperation with local authorities, the insolvency of residents through the interaction to achieve the goals of community;

- low level of qualification and professionalism of local self-government officials was the result of the low competitiveness of local authorities in the labour market and the low level of prestige of such posts; this problem was subsequently a result of a decrease in the effectiveness of managerial decisions;

- corporatization of self-government bodies, increasing corruption, secrecy and non-transparency of their activities;

- excessive resource and administrative centralization;

- lack of ubiquity of local self-government, in particular on resolving issues in the field of land relations.

To overcome the above problems of the local self-government development, the document [2] defines seven directions for the establishment of an effective management system at all levels and for the achievement of high-quality public services, namely:

- formation of an optimal territorial base as a basis for ensuring the development of local selfgovernment;

- ensuring the appropriate material, administrative, organizational and financial conditions for the implementation by local self-government of the authority granted to them;

- clear delineation of powers between governing bodies at various levels on the basis of decentralization;

- formation of an effective mechanism of state control over the activities of local authorities and the conformity of their management decisions with legislative and regulatory acts;

- development of direct democracy forms, the involvement of the population in the development of community;

- improving the coordination mechanism of local self-government.

Other legislative acts that have become fundamental since the beginning of the reform can be called the Law of Ukraine "On the voluntary unification of territorial communities", the Method for the formation of capable territorial communities, which determined the organizational basis for the ATC formation, etc. (Table 1). In accordance with the Methody, territorial communities of villages 
(townships, cities) are capable, which, as a result of voluntary amalgamation, are able to independently or through local governments provide an appropriate level of service, in particular in the field of education, culture, healthcare, social protection, housing and communal services economy, taking into account human resources, financial support and infrastructure development of the corresponding administrative and territorial unit [3].

The next step of the legislative and executive power branches was the adoption of the Plan for Legislative Support to Reforms in Ukraine [11], which was supposed to ensure consistency, comprehensiveness and defined clear guidelines for the reform. This plan determined a number of bills required for the adoption of their conceptual foundations, as well as deadlines and those responsible for their submission (Tab. 2).

The adoption of such a document at the beginning of the decentralization reform makes it possible today, given the completion of the voluntary amalgamation of the territorial communities and the "laying" of the foundations for enlarging the administrative and territorial units of the subregional level, to substantiate the state of the legislative support of the process and identify the risks that the adoption of the planned legislative acts entails.

First of all, it should be noted that today an effective regulatory framework has been formed for the decentralization reform in Ukraine. Although most of the regulatory acts in the field of decentralization were adopted in 2014-2015, today and in the future, legal support for this process is being formed, in particular in the context of overcoming the risks that have arisen after the completion of the initial stage of the reform. Among recently adopted documents:

\begin{tabular}{|c|c|c|c|}
\hline $\begin{array}{l}\text { Nature of } \\
\text { the } \\
\text { document }\end{array}$ & Name & $\begin{array}{l}\text { By and when } \\
\text { adopted }\end{array}$ & The conceptual framework, defined in the document \\
\hline \multirow{3}{*}{ 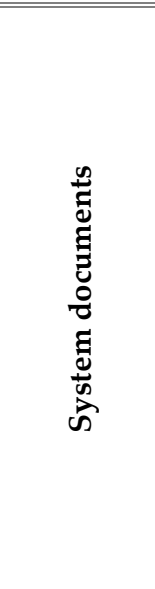 } & $\begin{array}{l}\text { On approval of the } \\
\text { Concept of reforming local } \\
\text { self-government and } \\
\text { territorial organization of } \\
\text { power in Ukraine }\end{array}$ & $\begin{array}{l}\text { The Order of the } \\
\text { Cabinet of Ministers } \\
\text { of Ukraine No. } 333 \text { - } \\
\text { p dated } 04 / 01 / 2014\end{array}$ & $\begin{array}{l}\text { reform goal is justified, the problems that should be } \\
\text { overcome in the process of implementing transformations } \\
\text { and the ways to solve them are clearly identified }\end{array}$ \\
\hline & $\begin{array}{l}\text { On the Sustainable } \\
\text { Development Strategy } \\
\text { "Ukraine } 2020 "\end{array}$ & $\begin{array}{l}\text { The Decree of the } \\
\text { President of } \\
\text { Ukraine No. 5/2015 } \\
\text { dated 01/12/2015 }\end{array}$ & $\begin{array}{l}\text { strategic document that outlines the principles for } \\
\text { implementing } 62 \text { reforms in Ukraine and identifies } \\
\text { indicators for their implementation }\end{array}$ \\
\hline & $\begin{array}{l}\text { On the principles of state } \\
\text { regional policy }\end{array}$ & $\begin{array}{c}\text { The Law of Ukraine } \\
\text { No. 159-VIII dated } \\
\text { 02/05/2015 }\end{array}$ & $\begin{array}{l}\text { aimed at determining legal, economic, social, } \\
\text { environmental, humanitarian and organizational } \\
\text { foundations of state regional policy in the context of } \\
\text { domestic policy of Ukraine }\end{array}$ \\
\hline \multirow{3}{*}{ 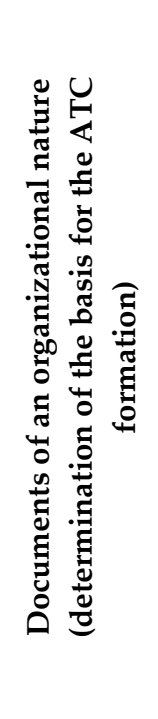 } & $\begin{array}{l}\text { On voluntary } \\
\text { amalgamation of territorial } \\
\text { communities }\end{array}$ & $\begin{array}{c}\text { The Law of Ukraine } \\
\text { No. } 157-19 \text { dated } \\
02 / 05 / 2015\end{array}$ & $\begin{array}{l}\text { features and conditions for the ATC formation are } \\
\text { identified, the main aspects of regulating the } \\
\text { relationships arising in the process of voluntary } \\
\text { amalgamation of territorial communities and voluntary } \\
\text { amalgamation to already established ATC are } \\
\text { substantiated }\end{array}$ \\
\hline & $\begin{array}{l}\text { On cooperation of } \\
\text { territorial communities }\end{array}$ & $\begin{array}{l}\text { The Law of Ukraine } \\
\text { No. } 1508-\text { VII dated } \\
06 / 17 / 2014\end{array}$ & $\begin{array}{l}\text { organizational and legal foundations of the cooperation } \\
\text { of territorial communities, the basic principles, forms } \\
\text { and mechanisms of such cooperation, the features of its } \\
\text { stimulation and financing, as well as control are } \\
\text { determined }\end{array}$ \\
\hline & $\begin{array}{l}\text { On approval of the } \\
\text { Methody for the formation } \\
\text { of capable territorial } \\
\text { communities }\end{array}$ & $\begin{array}{l}\text { The Resolution of } \\
\text { the Cabinet of } \\
\text { Ministers of } \\
\text { Ukraine No. } 214 \\
\text { dated } 04 / 08 / 2015\end{array}$ & $\begin{array}{l}\text { mechanism is formed and the conditions for the } \\
\text { formation of capable territorial communities are } \\
\text { determined, the need is justified and the procedure for } \\
\text { developing and approving a long-term plan for the } \\
\text { formation of community territories is established }\end{array}$ \\
\hline
\end{tabular}


Territorial Framework of Local Self-Government: Basis of... 151

\begin{tabular}{|c|c|c|c|}
\hline $\begin{array}{l}\text { Nature of } \\
\text { the } \\
\text { document }\end{array}$ & Name & $\begin{array}{c}\text { By and when } \\
\text { adopted }\end{array}$ & The conceptual framework, defined in the document \\
\hline \multirow{3}{*}{ 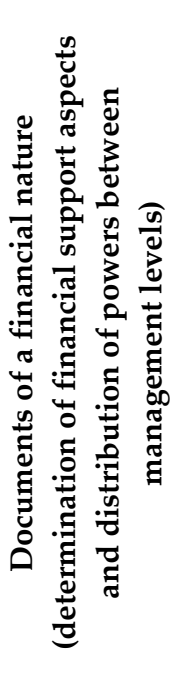 } & $\begin{array}{l}\text { On introducing } \\
\text { amendments to the Budget } \\
\text { Code of Ukraine regarding } \\
\text { the reform of inter-budget } \\
\text { relations }\end{array}$ & $\begin{array}{l}\text { The Law of Ukraine } \\
\text { No. } 79-19 \text { dated } \\
\text { 12/28/2014 }\end{array}$ & $\begin{array}{l}\text { features of the redistribution of budget revenues at } \\
\text { various levels and the introduction of a new system of } \\
\text { inter-budget equalization are justified; }\end{array}$ \\
\hline & $\begin{array}{l}\text { On introducing } \\
\text { amendments to the Tax } \\
\text { Code of Ukraine and some } \\
\text { legislative acts of Ukraine } \\
\text { regarding tax reform }\end{array}$ & $\begin{array}{l}\text { The Law of Ukraine } \\
\text { No. } 71-19 \text { of } \\
12 / 28 / 2014\end{array}$ & $\begin{array}{l}\text { features of tax collection and crediting of taxes as a result } \\
\text { of redistribution of revenues between budgets of different } \\
\text { levels are determined }\end{array}$ \\
\hline & $\begin{array}{l}\text { On making amendments to } \\
\text { the Budget Code of } \\
\text { Ukraine regarding the } \\
\text { features of the formation } \\
\text { and execution of ATC } \\
\text { budgets }\end{array}$ & $\begin{array}{l}\text { The Law of Ukraine } \\
\text { No. 837-VIII dated } \\
11 / 26 / 2015\end{array}$ & $\begin{array}{l}\text { interaction boundaries of the administrative-territorial } \\
\text { units' budgets in various levels are determined, the basis } \\
\text { for the formation and execution of local community } \\
\text { budgets is justified }\end{array}$ \\
\hline
\end{tabular}

Tab. 1. Legislative framework adopted in the context of supporting local self-government reform.

Source: compiled on the basis of [2, 3-10].

\begin{tabular}{|c|c|c|}
\hline Reform area & Title of the bill & Conceptual framework defined by the bill \\
\hline $\begin{array}{l}\text { Administrative } \\
\text { and territorial } \\
\text { structure }\end{array}$ & $\begin{array}{l}\text { On the administrative and } \\
\text { territorial structure of Ukraine }\end{array}$ & $\begin{array}{l}\text { A new three-level structure of the administrative and territorial } \\
\text { structure of Ukraine is provided, determination of the procedure for the } \\
\text { formation and liquidation of such units, changes in their borders, the } \\
\text { classification of settlements in one or another category }\end{array}$ \\
\hline \multirow{2}{*}{ } & $\begin{array}{l}\text { On amendments to the } \\
\text { Constitution of Ukraine } \\
\text { regarding the powers of state } \\
\text { authorities and local } \\
\text { authorities, territorial } \\
\text { organization of power, } \\
\text { decentralization }\end{array}$ & $\begin{array}{l}\text { The main reform guidelines were identified: 1) decentralization and } \\
\text { public administration reform; 2) reform of regional policy. It is } \\
\text { envisaged: 1) creation of conditions for the formation of capable } \\
\text { territorial communities and ensuring the omnipresence of local self- } \\
\text { government; 2) determination of ways to reduce the conflict between } \\
\text { local government and executive authorities through the delimitation of } \\
\text { their competencies in accordance with the principle of subsidiarity, } \\
\text { refusal to delegate the powers of district and regional councils to } \\
\text { executive authorities. }\end{array}$ \\
\hline & $\begin{array}{l}\text { On amendments to the Budget } \\
\text { and Tax Codes of Ukraine } \\
\text { regarding the allocation of } \\
\text { stable sources of income to } \\
\text { local budgets and the } \\
\text { expansion of the revenue base } \\
\text { of local budgets, while } \\
\text { ensuring the definition of } \\
\text { common rates of deductions } \\
\text { for personal income tax and } \\
\text { income tax of private sector } \\
\text { entities for each type at local } \\
\text { budgets }\end{array}$ & $\begin{array}{l}\text { In the context of the adoption of these changes, there is a need to ensure: } \\
\text { 1) adequate resource support for local self-government; 2) introduce a } \\
\text { horizontal system for equalizing the potential of local budgets by income. }\end{array}$ \\
\hline
\end{tabular}




\begin{tabular}{|c|c|c|}
\hline Reform area & Title of the bill & Conceptual framework defined by the bill \\
\hline \multirow{6}{*}{ 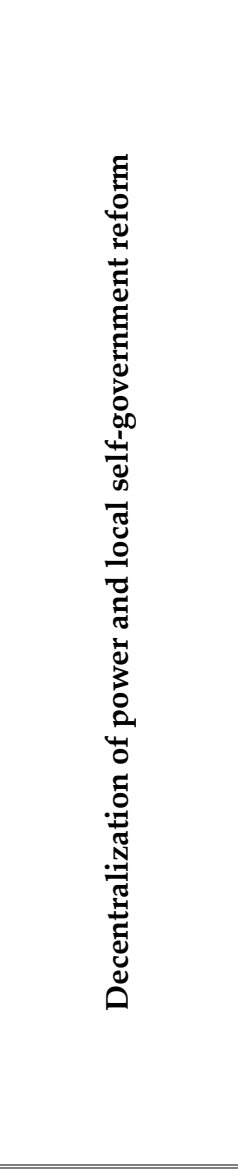 } & $\begin{array}{l}\text { On local self-government } \\
\text { authorities in Ukraine (new } \\
\text { edition) }\end{array}$ & $\begin{array}{l}\text { It is envisaged 1) to ensure a clear legal interpretation of the role of local } \\
\text { self-government in Ukraine; 2) providing the governing bodies with a } \\
\text { basic level of real authority to approach a citizen and increasing the } \\
\text { efficiency of providing public services; 3) the distribution of powers } \\
\text { between local authorities of the district and regional levels; 4) the } \\
\text { introduction of transparent mechanisms for administrative supervision } \\
\text { of public authorities in relation to local authorities. }\end{array}$ \\
\hline & On local executive authorities & $\begin{array}{l}\text { There is a regulatory justification for the creation process of the } \\
\text { executive bodies of the respective councils, which will take over part of } \\
\text { the powers of the central executive authorities, in particular to control } \\
\text { the activities of self-government bodies. }\end{array}$ \\
\hline & On local referendum & Must ensure legislative settlement of the local referendum issue. \\
\hline & $\begin{array}{l}\text { On self-organization bodies of } \\
\text { the population (new edition) }\end{array}$ & $\begin{array}{l}\text { Provides for the independence of the formation process of self- } \\
\text { organization bodies of the population from the will of local authorities }\end{array}$ \\
\hline & On municipal guard & $\begin{array}{l}\text { It should provide justification for: 1) the legal prerequisites for ensuring } \\
\text { the protection of law and order, respect for human rights and freedoms } \\
\text { in the context of decentralization; 2) granting the right to self- } \\
\text { government bodies to form municipal police at the expense of territorial } \\
\text { communities; 3) establishment of mechanisms for the implementation of } \\
\text { local authorities decisions in the field of legality, law and order and the } \\
\text { protection of rights and freedoms, interests of a citizen }\end{array}$ \\
\hline & $\begin{array}{l}\text { On making amendments to } \\
\text { some legislative acts of } \\
\text { Ukraine regarding cross- } \\
\text { border and regional } \\
\text { cooperation of local and } \\
\text { regional authorities } \\
\end{array}$ & $\begin{array}{c}\text { It envisages the introduction of regulatory standards for the creation and } \\
\text { activities of Euroregions, the formation of a coordination model of state } \\
\text { policy in the field of cross-border cooperation. }\end{array}$ \\
\hline $\begin{array}{l}\text { Service reform } \\
\text { in self- } \\
\text { government } \\
\text { authorities }\end{array}$ & $\begin{array}{l}\text { On service in local self- } \\
\text { government authorities (new } \\
\text { edition) }\end{array}$ & $\begin{array}{c}\text { It envisages the adoption of the Law of Ukraine "On Service in Local } \\
\text { Self-Government Authorities", based on European principles of public } \\
\text { service }\end{array}$ \\
\hline
\end{tabular}

Tab. 2. Legislative guidelines for decentralization reform and regional policy in Ukraine. Source: compiled on the basis of [11].

1) The Law of Ukraine "On Amending the Law of Ukraine "On the Voluntary Amalgamation of Territorial Communities" on the voluntary accession of territorial communities of villages and townships to territorial communities of regional significance cities" [12], which recognized territorial communities of regional significance cities as capable - the law was adopted in 2018 year in order to solve the problem of non-occupation of large cities by the process of ATC formation (this is due to the fact that cities, being in a winning position from transferring resources and powers to the local level, do not aground stimulus in association with the surrounding rural communities; besides, for the passage of a certain time there was a trend of failure of small villages to unite with the big city for fear of losing their own territory management and left the city without the amalgamation process);

2) The Law of Ukraine "On Amending Certain Laws of Ukraine regarding the status of village, township headman" [13], in particular in the context of amendments to the Law of Ukraine "On Service in Local Self-Government Authorities" [14], aimed at effectively regulating the activities of employees in local self-government authorities and increase the prestige of the service - such changes are aimed at overcoming the problem of the lack of qualified personnel in local self-government authorities and encouraging employees to provide high-quality public services and in the communities;

The Law of Ukraine "On Amending the Law of Ukraine "On the Voluntary Amalgamation of Territorial Communities" to simplify the procedure for approving long-term plans for the territory formation in communities of the Autonomous Republic of Crimea, regions" [15], adopted to simplify 
the procedure for approving long-term plans for the formation of community territories (the Law defines that, firstly, community amalgamation will continue only according to the long-term plan, and secondly, the procedure for creating long-term plans will no longer include an approval stage of these amendments by regional councils) - it is expected that in this way the politicization problem of local elites and their restraining influence on the process of community enlargement will be eliminated.

At the same time, it should be noted that the untimely and incomplete implementation of the Plan for legislative support to reforms in Ukraine in terms of decentralization and local self-government reform should be noted, since from the planned for adoption in 2015-2016 80\% of draft laws have not been adopted today. The bills that are fundamental for effective decentralization in Ukraine remain as adopted: "On the foundations of the administrative and territorial structure", "On amendments to the Constitution (regarding decentralization of power) ","On local executive bodies", "On the procedure for the formation, liquidation of districts", establishing and changing their borders, amending the Laws of Ukraine "On Local Self-Government","On Bodies of Self-Organization of the Population". Thus, the non-adoption of the law on the administrative and territorial structure of the state is accompanied by the uncertainty of the system of the territorial organization of power, and the delay in introducing amendments to the Constitution of Ukraine, which should coordinate at the legislative level the change in the administrative and territorial structure and the distribution of powers between governing bodies at various levels and the role of prefectures in the process development of territories, raises doubts about the irreversibility of the reform of local self-government in Ukraine.

\section{CONCLUSIONS}

Given the importance of these bills, it is worth noting that their rejection is accompanied by an increase in numerous risks and a slowdown in the implementation of local self-government reform, and may also be evidence of a lack of political will to complete it. Among other shortcomings and deficiencies in the system of legal and institutional support for the reform of local self-government are the following:

- poor coordination of the participants activities in the reform of local self-government at various levels (at the level of territorial communities, district, regional, central and subregional levels of government), at the moment it is manifested in the absence of a connection between the regional development policy and the decentralization process;

- lack of regulatory justification and distribution clarity of powers in areas that are characterized by a multi-level representation;

- weak links between the processes of reforming the local self-government system and sectoral reforms, resulting from the emergence of new risks and the inability of self-government bodies to respond in a timely manner to changes in the mechanisms for the provision of public services;

- lack of clear criteria for determining the impact of the ATC formation and development on the life quality of the population and clear boundaries of managerial freedom of local self-government authorities.

Therefore, it should be noted that only a qualitatively formed regulatory and legal framework will serve as the basis for the ability and functionality of the amalgamated territorial communities.

\section{REFERENCES}

[1] Kuybida V.G. (Ed) Administrative and territorial structure of Ukraine. History. Modernity. Perspectives. Secretariat of the Cabinet of Ministers of Ukraine. Geoprint, Kyiv, 2009. (in Ukrainian) 
[2] Cabinet of Ministers of Ukraine. On Approval of the Concept of Local Governance and Authorities' Territorial Organization Reforming in Ukraine. Resolution № 333-r as of 1 April 2014. (2014). Avaolable at: https://zakon.rada.gov.ua/laws/show/333-2014-p (in Ukrainian)

[3] Cabinet of Ministers of Ukraine. (2015). On Approval of the Methodology of Forming of Capable Territorial Communities. Resolution of the Cabinet of Ministers of Ukraine. № 214 as of 8 April 2015. (2015). Available at: https://zakon.rada.gov.ua/laws/show/214-2015-п (in Ukrainian)

[4] President of Ukraine. On Sustainable Development Strategy “Ukraine - 2020". Order of the President of Ukraine № 5/2015 as of 12 January 2015. (2015). Available at: https://zakon.rada.gov.ua/laws/show/5/2015 (in Ukrainian)

[5] Verkhovna Rada of Ukraine. On Voluntary Consolidation of Territorial Communities. Law of Ukraine № 157-19 as of 5 February 2015. (2015). Available at: https://zakon.rada.gov.ua/laws/show/157-19 (in Ukrainian)

[6] Verkhovna Rada of Ukraine. On Cooperation of Territorial Communities. Law o Ukraine № 1508-VII as of 17 June 2014. (2014). Available at: https://zakon.rada.gov.ua/laws/show/1508-18 (in Ukrainian)

[7] Verkhovna Rada of Ukraine. On foundations of Public Regional Policy. Law o Ukraine № 159-VIII as of 5 February 2015. (2015). Available at: https://zakon.rada.gov.ua/laws/show/156-19 (in Ukrainian)

[8] Verkhovna Rada of Ukraine. On Amendments to the Budgetary Code of Ukraine Regarding the Reform of Interbudgetary Relations. Law of Ukraine № 79-19 as of 28 December 2014. (2014). Available at: https://zakon.rada.gov.ua/laws/show/79-19 (in Ukrainian)

[9] Verkhovna Rada of Ukraine. On Amendments to the Tax Code of Ukraine and Several Regulations of Ukraine Regarding the Tax Reform. Law of Ukraine № 71-19 as of 28 December 2014. (2014). Available at: https://zakon.rada.gov.ua/laws/show/71-19 (in Ukrainian)

[10] Verkhovna Rada of Ukraine. On Amendments to the Budgetary Code of Ukraine Regarding the Peculiarities of Forming and Execution of CTCs' Budgets. Law of Ukraine № 837-VIII as of 26 November 2015. (2015). Available at: https://zakon.rada.gov.ua/laws/show/837-19 (in Ukrainian)

[11] Verkhovna Rada of Ukraine. Plan of Legal Framework of Reforms Maintenance in Ukraine. Resolution of Verhovna Rada of Ukraine № 509-VIII as of 4 May 2015. (2015). Available at: https://zakon.rada.gov.ua/laws/show/509-19 (in Ukrainian)

[12] Verkhovna Rada of Ukraine. On Voluntary Consolidation of Territorial Communities Regarding the Voluntary Incorporation of Territorial Communities of Villages and Towns in Territorial Communities of Cities of Oblast Significance. Law of Ukraine № 2379-VIII as of 3 April 2018. (2018). Available at: https://zakon.rada.gov.ua/laws/show/2379-19 (in Ukrainian)

[13] Verkhovna Rada of Ukraine. On Amendments to Several Laws of Ukraine Regarding the Status of the Heads of Villages and Towns. Law of Ukraine №1848-VIII as of 9 February 2017. (2017). Available at: https://zakon.rada.gov.ua/laws/show/1848-19 (in Ukrainian)

[14] Verkhovna Rada of Ukraine. On Service in Local Governance Authorities. Law of Ukraine № 2493-VIII as of 28 November 2019. (2019). Available at: https://zakon.rada.gov.ua/laws/show/2493-14 (in Ukrainian)

[15] Verkhovna Rada of Ukraine. On Amendments to the Law of Ukraine "On Voluntary Consolidation of Territorial Communities" Regarding the Simplified Procedure of Approval of Perspective Plans of Territorial Communities Forming in the Autonomous Republic of Crimea, Oblasts. Law of Ukraine №348-IX as of 5 December 2019. (2019b). Available at: https://zakon.rada.gov.ua/laws/show/348-20

Address: Zinoviy Siryk, Lviv Polytechnic National University, 12 Stepana Bandery St., Lviv, 79000 Ukraine; Rostyslav Bilyk, Yuriy Fedkovych Chernivtsi National University, 2 Kotsjubynskyi St., Chernivtsi 58012 Ukraine;

Olena Panukhnyk, Ternopil Ivan Puluj National Technical University, 56 Ryska St., Ternopil, 4600 Ukraine.

E-mail: zsiryk62@gmail.com, rostikbiluk78@gmail.com, panukhnyk@gmail.com

Received: October 7, 2020; revised: November 9, 2020. 
Сірик Зеновій, Білик Ростислав, Панухник Олена. Територіальна основа місцевого самоврядування: основи законодавчого регулювання. Журнал Прикарпатського університету імені Василя Стефаника, 7 (3) (2020), 147-155.

Україна все активніше намагається інтегруватися в Европейські структури. Цивілізаційний, геополітичний та геоекономічний вибір для нашої країни є очевидним, а тому для його реалізації необхідні важкі, послідовні та інколи нетрадиційні й непопулярні політичні рішення. Необхідне реальне втілення принципів деконцентрації, децентралізації та субсидіарності в практику державного управління, зокрема через запровадження нових моделей взаємовідносин між політичним центром та регіонами. Регіональні диспропорції розвитку території України, неспроможність реалізації реформи на місцях в конкретних адміністративно-територіальних одиницях, поширення корупційних схем - все це наслідки неефективної моделі місцевого самоврядування та державного управління регіональним розвитком і саме ці процеси стали початком адміністративнотериторіальної реформи в державі. А для того щоб забезпечити якісний процес адміністративнотериторіальної реформи важливим, а в деякій і мірі і найосновнішим є процес прийняття якісного нормативно-правового за законодавства. У статті визначено основні напрями становлення ефективної системи управління на усіх рівнях, серед яких: формування оптимальної територіальної основи, забезпечення відповідних матеріальних, адміністративно-організаційних та фінансових умов для реалізації органами місцевого самоврядування наданих їм повноважень, чітке розмежування повноважень між органами управління різних рівнів на основі децентралізації, розвиток механізму державного контролю та залучення населення до розвитку громади. Проаналізовано законодавчу базу, яка була прийнята в контексті супроводу реформи місцевого самоврядування в Україні. Визначено та обгрунтовано законодавчі орієнтири реформи децентралізації та регіональної політики в Україні. Визначено недоліки та не доопрацювання системи нормативно-правового та інституційного забезпечення реформи місцевого самоврядування та запропоновано шляхи їх усунення.

Ключові слова: адміністративно-територіальна реформа, децентралізація, органи самоврядування, нормативно-правова база, територіальні громади. 